\title{
The Citizen's Guide to Climate Success - Overcoming myths that hinder progress
}

Mark Jaccard. 2019. ISBN-978-110-874-2665 Cambridge University Press, New York, N.Y. \$ US 19.95 + shipping. Contact: drissetto@cambridge.org

$\boldsymbol{T}_{\mathrm{c}}^{\mathrm{h}}$ he Citizen's Guide to Climate Change is an informative and lucid read. It takes a very complex topic and gives it an effective and I feel, a unique and enlightening interdisciplinary treatment. Dr. Jaccard integrates current climate science and the drive to get our greenhouse gas (GHG) emissions to net zero with relevant infusions of economics, politics, public policy, history, psychology and sociology. There is even some mildly bawdy humour to be found, when he shares the somewhat surreptitious work of one of his grad students-on the carbon footprint of our sex lives. I am not sure if that student's data accounted for the unfortunate diminishing of such amorous activity as our population ages; however at least anecdotally my friends and I could weigh-in on this pervasively sad situation. Dr. Jaccard manages to do all of this at what for me was just the right cerebral level. You must read this guide deliberately-thinking rationally and with a completely open mind, and it is well worth that effort. Upon finishing the Guide, I feel as though I've taken a top-quality short course from not only a competent scientist, but a great communicator-a potent and powerful combination.

To many of us, effectively addressing climate change at a global scale seems the ultimate challenge and perhaps even almost illusory, and it is also difficult and confusing for many of us personally to understand what meaningful changes we can make in our day-to-day lives to contribute to the cause. Dr. Jaccard's roadmap clarifies these challenges and issues, and clearly presents the best-bet solutions and opportunities that can and will make a difference. He shares his comprehensive knowledge and experience with us, and honestly examines the myths and misinformation that are causing a generally slow pace of change around the world. Dr.
Jaccard's lucid analysis identifies the essential actions that will ultimately bring-about success-i.e., the need to decarbonize electricity production and transportation, implement policies and regulations that phase out coal plants and gasoline vehicles, and a system of judiciously implemented and consistent carbon tariffs by developed countries.

I had hoped when I started to read the Guide that the overall tone of the book would be at least somewhat optimistic-it definitely is in my opinion, even more than I had wished. Despite the slow pace of change in most countries, particularly in the form of collective, consistent and sustained government policies, there is reason to believe that we will ultimately be successful in bringing about zero net emissions of GHGs before it is too late. What jumped out for me specifically included a clear articulation by Dr. Jaccard of what public policies actually work best and where there has been success, and also a strong indication that we essentially already have the technologies to make zero net emissions happen! Dr. Jaccard also focuses on what we need with respect to effective and consistent climate leadership at the political level and the corollary of ending the generally endemic climate action foot-dragging. Perhaps most importantly, he covers how we can and should deal with our own personal climate beliefs and biases to better inform and enlighten ourselves and thus contribute more willingly and more confidently to concerted and successful climate solutions.

Dr. Jaccard's strong emphasis on the need to identify and support climatesincere politicians who will not only implement but maintain and follow through on the policy changes needed, is a strongly resonating and timely message. As I write this review, Canada is in the midst of rail blockades relating to

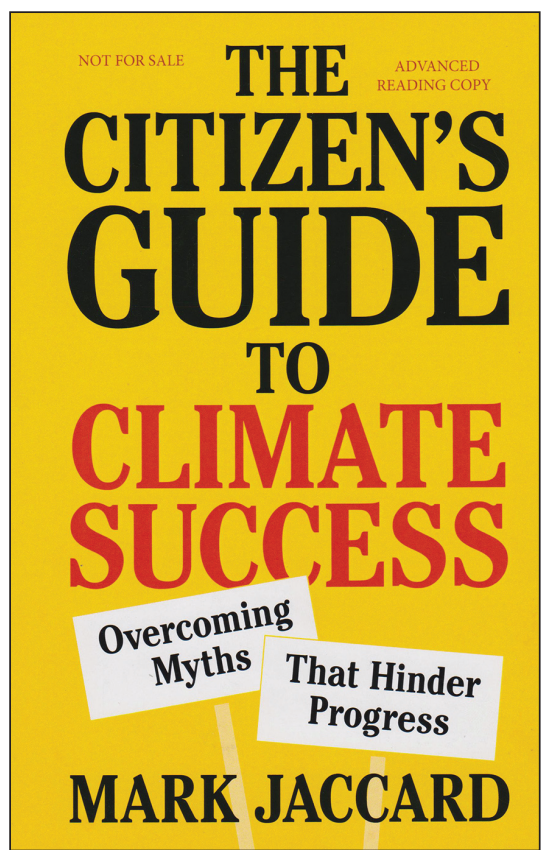

disagreement around a new natural gas pipeline on the Wet'suwet'en First Nation traditional territory in British Columbia. Even the most climate-sincere politicians will find the complexity, deep divisions and raw emotion relating to such circumstances extremely difficult to navigate. I ponder often what our future will be in Canada with such pervasive polarizing issues and viewpoints, particularly relating to resource development and Indigenous reconciliation, made much more complex within the context of much needed climate change solutions becoming the norm. Also for some wanting to identify and vote-in truly climate sincere politicians, those politicians' platforms will come with an array of positions on other issues, or with dogmas and policies that are often individually unpalatable enough to deflect votes that might otherwise support concerted, long-term policies and action leading to carbon 
neutrality. Interestingly Dr. Jaccard uses one of the Guide's chapters to refute the position of a well-known advocate for socialism - that somehow the end of capitalism is a requirement to achieve climate success. He does this by making a strong case that this mix unnecessarily convolutes an already complex and challenging issue with other, and certainly in this case, very controversial and polarizing political and social agendas; it is not a path forward and in fact would be quite detrimental in achieving climate success.

In summary, I feel that the Guide is a cautious argument for climate optimism, and I admit openly that it changed some of my own personal biases and beliefs for the better. I think it could and should help to better inform many, including politicians of all stripes, to make the best possible decisions. Rather than feeling helpless and pursuing non-impactful approaches, we can all make a few key changes in our outlooks and lifestyles to reduce emissions, and to contribute to affordable energy transition in our own country and in other parts of the world. For success in eventually achieving net zero emissions, we must thoughtfully direct our efforts as citizens and as a country on key sectors, especially electricity and transportation, and on implementing policies that have proven their effectiveness in other jurisdictions. As developed countries decarbonize their electricity and transportation sectors, various means including the implementation of carbon tariffs can help to spread the impetus to further reduce GHG's throughout the world.

For more on this excellent book, you can visit Dr. Jaccard's blog at markjaccard.com

\section{Reviewed by John Pineau}

Provincial Leader Ontario FPInnovations

\section{Forests Adrift - Currents Shaping the Future of Northeastern Trees}

Canham, Charles D. 2020. ISBN 78-0-300-23829-7, Yale University Press, 222 p.

$\mathbf{T}^{\mathrm{h}}$ his is a book of twelve chapters in which the author, a forest ecologist, gives a personal account of his experiences starting with his growing up in the Hudson Highlands of New York where he came to know the trees of the northeastern forests of the United States. From his graduate student days in the mid-west, he was familiar with F.E. Clements' theory of climax and the concept of succession as well as the views of Gleason and others who challenged Clements. But as he states, "I have never found the need to put names or discreet boundaries on the communities I see around me". His observations of the forests he worked in caused him to consider important the responses by different tree species to openings and gaps of various kinds and degrees. He deals at some length with the nature of pre-settlement forests and the period of massive agricultural settlement in the northeastern states followed by the logging of the subsequent forests. By 1900, 85\% of New England had been cleared to create an agricultural landscape, whereas to-day $70 \%$ is now a forested landscape. The nature of forest disturbances, natural or of human origin, their frequency, duration, extent and timing are recurring features of most forests, of which any forester or forest ecologist must be aware.

Not only the recognition of disturbances but the continued documentation of the composition of specific forests over time can be a valuable source of information for any person looking at the responses of tree species over these periods. Canham cites the importance of the United States Forest Service Forest Inventory and Analysis program, initiated in the 1930s by a concern about future timber supply in the U.S. This program, which in 1988 was joined by a Forest Health Monitoring Network in many states, provides invaluable information about the nature and changes in American forests on all forest ownerships, public and private, because of its periodic, variously annual, five yearly or ten year cycles of measurements on the same plots.

Several chapters deal with the nature of specific forms of forest disturbance, such as chapters 3 and 4 with early clearing and logging; chapters 5 on fire and 6 on white-tailed deer are of particular interest because of the results of public policies and the way in which, currently, we now view their management. For fire, the switch has been from a policy of

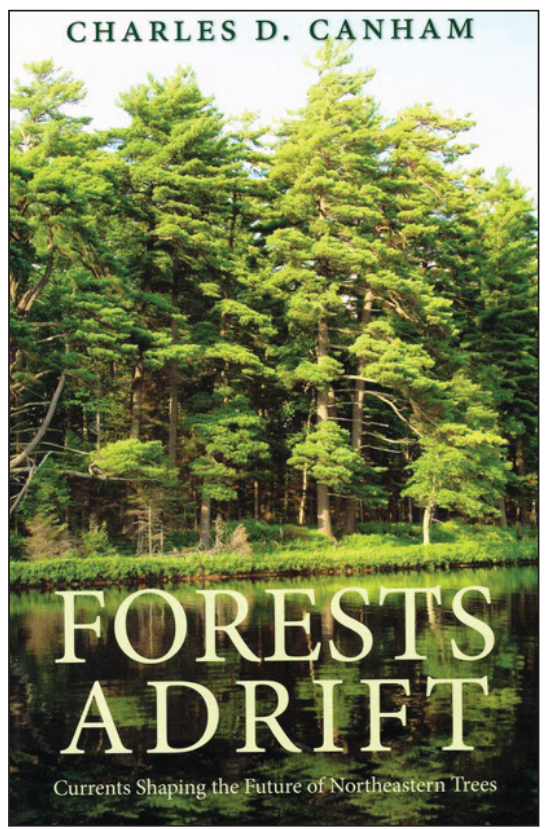

suppression to a recognition that management of fire in terms of intensity and frequency can be important silvicultural tools. Canham notes an interesting shift between maple and oak species in New England's southern forests, where differences in shade tolerance and tolerance to fire have favoured maples over oaks. The differences between maple and oak litter, the former producing a flat mat on the forest floor while the latter curl up and in the spring are a fuel for a ground fire, he sees as bringing about a fundamental change in the forest 
ecosystem. However, attempts to use fire as a silvicultural tool to preserve oak forests have had mixed results and Canham discusses at some length possible reasons for this. Chapter 6, "The Fall and Rise of White-tailed Deer" is of interest because, although the reduction in forest cover following settlement and then its increase to the present was associated with the reduction and then increase in the deer population, he does not see a causal connection but rather the influence of public policy and hunter education. There is no doubt that deer in their current number have a direct effect by browsing on certain species such as hemlock but also on many understory non-tree species. Despite attempts to control deer numbers he notes, "I've begun to wonder if hunters' recent worries about seeing fewer deer each year are simply due to smarter deer and older less mobile hunters". He does conclude that where a deliberate and consistent hunting program, as practiced at the Cary Institute of Ecosystem Studies in New York is undertaken, deer density can be controlled.

Chapter 7 is titled, "A Sea Change in Logging" and he asserts at the beginning that many ecologists and foresters view the historical wave of clearcutting in the past as having left a landscape of evenaged forests, but this is no longer the case with the introduction of new harvesting practices. Not only is this historical view of clearcutting no longer pertinent but it is, I would say, ingrained in the public's view of forestry. Certainly, as Canham states, "There has been an uneasy truce between ecologists and foresters." He makes an interesting point that ecologists have focused studies on successional changes after clearcutting but not on the effects of other silvicultural practices in managed forests. He discusses the effects of current patterns of harvesting as affecting the sustainability of the northeastern forests in terms of biomass production and also in terms of carbon sequestration. One of the measures he uses is the proportion of forests in early, mid, late successional stages or as old growth. The forests of Maine stand out against those of the other northeastern states due to the nature of the Maine forests-largely coniferous-and the associated silvicultural system of clearcutting used. He takes issue with the harvesting of low quality wood for pulp or biomass energy uses instead of leaving it as standing timber to be marketed as carbon offsets. He acknowledges the influence of social and economic factors such as urban development encroaching on forests close to cities and towns and the differences associated with sizes of private woodland ownerships as influencing the availability of forests for harvesting. One factor such as fashion, or what he calls the "Martha Stewart effect", depends on the consumer tastes, for example, lightcoloured woods such as maple instead of oak or cherry for cabinets and furniture, therefore those are the species harvested. If there is any dissonance in this chapter, it is his sudden introduction, purportedly of tree genetics and tree quality, with a discussion of beech bark disease. Otherwise this chapter raises many issues about the future of the northeastern forests which clearly can form the basis for vigorous debate.

The next three chapters deal with external factors that continue to affect the growth of trees and forests. Chapter 8, "Change is in the Air", starts with the effects of acid rain, which from the early 1950 s to the 1990s was a prominently featured item in the public media, but is now more of scientific interest as we learn more about nitrogen additions from the air and the impacts of rising $\mathrm{CO}_{2}$ levels on forest growth. Chapter 9, "New and Unwelcome Passengers", begins with a brief look at species and their geographic distribution through geologic time, before dealing generally with the issue of invasive species. While the focus has been primarily on plant species, we now look at fungi and earthworms whose presence in the soil rooting zone can affect tree growth. Overall, Canham concludes that the threats by invasive species to northeastern forests pales in comparison with the threats to wetlands, rivers and lakes. Chapter 10, "A Far More Threatening Invasion", is an extension of the previous chapter but deals with pests and diseases. The most valuable part is the Table of what he calls a rogues gallery of introduced forest pests and pathogens on northeastern forest tree species. Their introduction, beginning in the $19^{\text {th }}$ century, often from introduced plants, has now accelerated from increased trade involving wood packaging, for example, the emerald ash borer. He takes issue with the concept of "foundational species". This is a term used to describe a tree species whose disappearance alters the environment and transforms the ways in which the ecosystem functions. The term was used to describe hemlock and Canham sees no reason why other northeastern tree species couldn't be elevated to the foundational status and secondly, since the choice of hemlock was related to its loss to the woolly adelgid and hemlock scale, he sees the impact of the emerald ash borer, especially on black ash growing in wetlands, as another candidate for being rated as a foundational species. Such a focus he considers unjustified, since he basically sees every tree species as having a unique set of traits and impacts on ecosystem functions. He sees no end to the effects of invasive pests and diseases in the long-run.

In Chapter 11, "Storm Clouds Looming", Canham sees introduced pests and pathogens as continuing to wreak havoc in the northeastern forests. While acknowledging that climate change overall is the greatest environmental challenge, he concludes that it will have little immediate impact on the northeastern tree species with the exception of balsam fir and white spruce. This is because the other tree species, which are either saplings or in the canopy stages, can withstand variations in temperature and precipitation. It is seedlings of these trees which are most vulnerable to the changes brought about by climate change and which will affect the long-term composition of the northeastern forests. He sees oaks and hickories displacing maple and beech but, then in turn, being influenced by the assumed combined effects of continued fire suppression, deer browsing and selective logging, so that he postulates that white pine and tulip poplar will ultimately be the prevailing species. In a more general consideration of the distribution of many northeastern tree species in relation to ranges of mean annual temperatures, he concludes that seedling establishment is the critical life history stage, and once established, factors other than climate will determine its abundance. He considers that the northeastern forests will be more 
resilient to impending changes such as climate than other ecosystems in the United States.

Finally in Chapter 12, "What Lies Ahead", he starts by retracing his walk as a teenager in the woods of the Hudson Highlands with its tranquility he now realizes, after some 40 years, that there is a history and also an emergence of new landscapes that had no precedent. He recognizes the fact that changes in the forests are inexorable, whether due to pests and diseases or the depletion of calcium from forest soils by acid rain. Returning to the book's title, he sees the composition of these forests as drifting in response to the many diverse forces that buffet them-biotic and abiotic-but also that the pace of change will increase. This is a personal account by an observant and thoughtful forest ecologist who can relate to these northeastern forests from his earliest experiences as a young boy to his work in them over a period of several decades. He concludes on a positive note that these forests are seaworthy despite the many currents at work.

Reviewed by

Ken Armson, O.C., R.P.F. (retired)

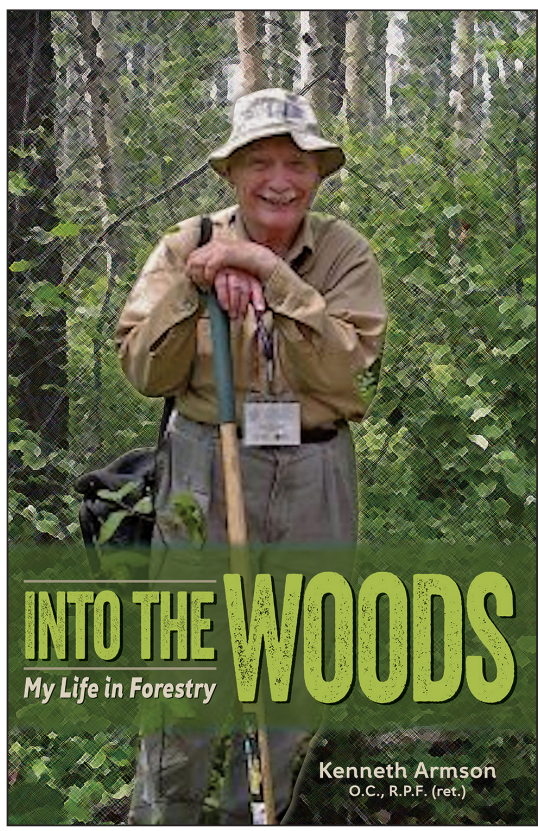

tainer seedling production, silviculture practices, civil service work, frustrations with forest policy and bureaucracy, forestry research, and the list continues.

I urge all wannabe, practicing, and retired foresters to get and read this fascinating story of the life of one of Canada's most influential foresters. You will see yourself, either by name or by example, but you will also get a better appreciation for how the work of others is shaping, or has shaped, the framework for your own career.

Malcolm F. Squires R.P.F. (Ret.) Thunder Bay, Ontario 